\title{
The gabbro dacite blend as soil remineralizer
}

\author{
Fábio Júnior Pereira da Silva ${ }^{1}$, André Mundstock Xavier de Carvalho ${ }^{2 *} \oplus$, Pedro Henrique de Castro Borges ${ }^{2} \Subset$ \\ ${ }^{1}$ AS-PTA, Rio de Janeiro, RJ, Brasil. E-mail: fabio@aspta.org.br \\ ${ }^{2}$ Universidade de Viçosa, Instituto de Ciências Agrárias, Rio Paranaíba, MG, Brasil. E-mail: andre.carvalho@ufv.br; pedrohborgesufv@gmail.com
}

ABSTRACT: The present study aimed to evaluate the ability of a mixture of gabbro powder and dacite powder to promote plant growth, provide nutrients and alter soil chemical characteristics. Two experiments were conducted under different field conditions, in which black oat and beans were added with increasing doses ( 0 to $\left.10 \mathrm{t} \mathrm{ha}^{-1}\right)$ of the powder rock blend. The grain yield (beans), dry matter production (oats) and the nutritional status of the crops were evaluated. At the end of the experiments, soil samples were collected and subjected to chemical analysis. The application of the rocks resulted in an increase in bean productivity corresponding to $440 \mathrm{~kg} \mathrm{ha}^{-1}$ at the dose of $7 \mathrm{t} \mathrm{ha}^{-1}$ in relation to the control. The application of the blend also resulted in an overall improvement in most commonly fertility parameters used, although this improvement was more evident only for phosphorus, copper, and zinc nutrients. In addition, the application of the rock mixture resulted in an increase in the foliar contents of potassium, zinc, copper, and manganese nutrients. Therefore, the material obtained by the mixture of gabbro and dacite, in the proportion of mixture tested, can be considered a multi-nutrient source with evident agronomic viability.

Key words: Avena strigose; basalt powder; latite; Phaseolus vulgaris; powder rocks

\section{O blend gabro dacito como remineralizador de solo}

RESUMO: O presente estudo teve como objetivo avaliar a capacidade de uma mistura de pó de gabro com pó de dacito em promover 0 crescimento de plantas, fornecer nutrientes e alterar características químicas do solo. Dois experimentos foram conduzidos em condições de campo distintas, nos quais foram cultivados aveia preta e feijão adicionados de doses crescentes ( 0 a 10 t ha $\left.^{-1}\right)$ do blend de rochas. Foram avaliadas a produtividade de matéria seca (aveia) e grãos (feijão) e 0 estado nutricional das culturas. Ao final dos experimentos, amostras compostas do solo foram coletadas e submetidas às análises químicas. A aplicação das rochas resultou em um aumento na produtividade de feijão correspondente a $440 \mathrm{~kg} \mathrm{ha}^{-1}$ na dose de $7 \mathrm{t} \mathrm{ha}^{-1}$ em relação a testemunha. A aplicação do blend também resultou em melhoria global dos parâmetros de fertilidade mais comumente empregados, embora esta melhoria tenha sido mais evidente apenas para os nutrientes fósforo, cobre e zinco. Além disso, a aplicação da mistura de rochas resultou em aumento nos teores foliares dos nutrientes potássio, zinco, cobre e manganês. Portanto, o material obtido pela mistura de gabro e dacito, na proporção de mistura testada, pode ser considerado uma fonte multinutriente com evidente viabilidade agronômica.

Palavras-chave: Avena strigosa; pó de basalto; latito; Phaseolus vulgaris; rochagem

*André Mundstock Xavier de Carvalho - E-mail: andre.carvalho@ufv.br (Corresponding author) Associate Editor: Mário de Andrade Lira Júnior

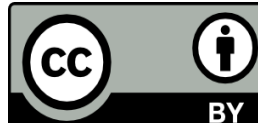

This is an open-access article distributed under the Creative Commons Attribution 4.0 International License. 


\section{Introduction}

Some silicate rocks have been shown as possible alternatives for the addition of nutrients to the soil from sources available regionally. The use of these materials in agriculture minimizes the impacts of quarrying and mining activities, reducing their tailings deposits and providing a useful destination for these materials (Tavares et al., 2018). In addition, silicate rock powders, or remineralizers, can reduce Brazil's external dependence on fertilizers and strengthen local productive arrangements through the decentralization of fertilizer suppliers. Last but not least, because they are natural inputs with use permitted by national and international standards for organic food production, research on remineralizers meet demands for products that suit this growing segment (Willer et al., 2021).

Some studies have shown satisfactory results in the use of rock powders as acidity correctors (Melo et al., 2012; Mancuso et al., 2014) and addition of nutrients to the soil (Shamshuddi \& Anda, 2012; Silva et al., 2012; Machado et al., 2016; Ramos et al., 2017; Souza et al., 2018; Tavares et al., 2018; Basak et al., 2021). However, the real capacity of these materials to provide an expressive amount of nutrients in the short term is not consensual (Gotz et al., 2019). However, Carvalho et al. (2018) points out that the results unfavorable to the use of silicate rocks are mostly associated to short-term experiments in a controlled environment, with the use of sterile soils or substrates with low microbial activity/diversity, very low temperature and humidity in addition to very small amounts or powders with very large particles. These conditions restrict the speed of the reactions, the microbial activity and, thus, the availability of the nutrients present.

On the one hand the low solubility of these materials is pointed as the main limitation of these sources of nutrients. On the other hand, the low solubility allows a gradual release of the nutrients to the soil, allowing a single application of all the fertilizer at the beginning of the crop (Carvalho et al., 2018). This may contribute to the reduction of machine traffic to application installment activities and reduce nutrient leaching losses.

In addition to being essential sources of nutrients, silicate rocks have elements that are beneficial to plant metabolism and toxic elements. Among these, the silicon ( $\mathrm{Si}$ ) stands out as the most abundant constituent in these rocks. The benefits of this element are related to the induction of resistance in plants, activating genes responsible for the synthesis of secondary metabolites related to the defense mechanisms. Fertilization with Si can also reduce the severity of plant diseases (Wang et al., 2017). Silicate rocks also have varying levels of essential elements beneficial to human and animal nutrition. These elements are not considered in fertilization because they are not essential to plants, such as Se, Co, V, La, $\mathrm{Li}$, I and others. Plants need only 14 essential elements, while humans need more than 20 essential and beneficial elements (Zoroddu et al., 2019).
The magnitude of the effects associated with the application of silicate rock powders depends on some factors such as: soil chemical conditions, powder granulometry, chemical and mineralogical composition of the rock, size and quality of crystals, among others. In general, the elements are available in the medium to long term and due to the weathering of the material and can be accelerated by the removal of the soluble products from the sources. Such removal may be further enhanced by biological factors, such as the extraction and absorption of these products by plants and soil microbiota (Carvalho et al., 2018).

Volcanic igneous rocks of the Serra Geral formation are generally known in Brazil as basalts, although they include basalt-dacites, gabbro, basalt-andesites, amygdaloidal basalts, among others. In general, they are basic rocks with higher levels of iron-magnesian minerals, dark colors and aphanitic texture. These characteristics are often associated with the higher reactivity and richness in $\mathrm{Ca}, \mathrm{Mg}$ and micronutrients of these rocks in relation to the plutonic igneous rocks or to the most common metamorphic rocks, although they are also associated with the lower richness in $\mathrm{K}$. It is important to consider that many silicate rocks have relatively high amounts of several essential nutrients, which is why they can be understood as potential multi-nutrient fertilizers (Swoboda et al., 2021).

An important amount of work in the literature points to the benefits of using basalt powders in agriculture. Ramos et al. (2020), for example, demonstrated increases in CEC, availability of macronutrients ( $P, K$ and $S$ ) and micronutrients ( $\mathrm{Cu}, \mathrm{Mn}$ and $\mathrm{Zn}$ ). In addition, these and other authors observed neutralization of exchangeable aluminum, availability of $\mathrm{Si}$ and increase of $\mathrm{pH}$ in different types of soils (Shamshuddin \& Anda, 2012; Ramos et al., 2020). The effects of the use of basalt powder are diverse, being reported in several works of the literature. However, some studies have also shown no or reduced effect of this rock (Gotz et al., 2019), which evidences the need to understand the various conditions that control the magnitude of desirable effects. However, no dacite or gabbro agronomic work has been found in the international literature to date.

Thus, in the present study we aimed to evaluate the ability of a gabbro powder mixture with dacite powder to promote plant growth, provide nutrients and alter soil chemical characteristics.

\section{Materials and Methods}

\section{General characterization}

The works were conducted by the Universidade Federal de Viçosa - Campus Rio Paranaíba, in partnership with Ekosolos Company. Two experiments, under the same experimental matrix, were conducted under field conditions in the municipalities of Paula Freitas - PR, Brazil, and Porto Vitória - PR, Brazil, in the agricultural year of 2017-2018. The experimental environments were agricultural areas under the presence of a Latossolo Bruno ( $26^{\circ} 08.269^{\prime} \mathrm{S}, 50^{\circ} 46.301^{\prime} \mathrm{O}$, 
792 m of altitude, Paula Freitas - PR, Brazil) and a Cambissolo Háplico $\left(26^{\circ} 12.665^{\prime} \mathrm{S}, 51^{\circ} 14.943^{\prime} \mathrm{O}, 885\right.$ m of altitude, Porto Vitória - PR, Brazil). These areas were chosen according to the edaphic differences presented, being the first one under a soil of sedimentary materials of the Poço Preto formation and the second under a soil formed from igneous materials of the Serra Geral formation. A composite soil sample of the areas, 0-20 cm layer, was collected with Dutch auger and its characterization is described in Table 1.

The evaluated material was a mixture of the gabbro and dacite rocks, whose chemical and mineralogical characterization is presented in Table 2. The gabbro powder was obtained from a quarry located in Paula Freitas - PR, Brazil (26 $\left.16^{\prime} 45^{\prime \prime} \mathrm{S} ; 50^{\circ} 57^{\prime} 23^{\prime \prime} \mathrm{W}\right)$ and the dacite powder was obtained from a quarry located in Porto União - SC, Brazil $\left(26^{\circ}\right.$ $\left.23^{\prime} 31^{\prime \prime} \mathrm{S} ; 51^{\circ} 15^{\prime} 12^{\prime \prime} \mathrm{W}\right)$. Both materials were obtained only by grinding and sieving processes in a mesh size of $<1 \mathrm{~mm}$. The final product was obtained by mixing $30 \%$ dacite powder with $70 \%$ gabbro powder (bulk ratio).

\section{Experimental design}

The experiments consisted of five treatments corresponding to the five doses of rock powder, equivalent to $0,2,4,7$ and $10 \mathrm{tha}^{-1}$. The experiments were assembled in a randomized block design (Experiment I - Porto Vitória - PR, Brazil) and in a completely randomized design (Experiment II - Paula Freitas - PR, Brazil), both with five replications of each treatment. Each experimental unit consisted of a square plot of $16 \mathrm{~m}^{2}$. The rock powder was applied at all doses, in total area and incorporated at the time of planting. Each treatment was reapplied in the sowing of the two cultures evaluated.
The test cultures were black oat (Avena strigosa L.) (Embrapa 139 "Neblina") and common bean (Phaseolus vulgaris L.) ("Taquara" variety) grown in succession under the same area, the first being sown in July 2017 and the second in November 2017. Oats were sown at the usual dose of $80 \mathrm{~kg} \mathrm{ha}^{-1}$ of seed. The bean was sown in line (line spacing of $0.50 \mathrm{~m}$ ) and manual sieving to reach the stand corresponding to 10 plants $\mathrm{m}^{-1}$ linear.

Approximately 20 days before planting oats, a basic fertilization of triple superphosphate was carried out according to the recommendations of SBCS-RS/SC (2004). Other pest management practices were performed according to the usual for the crop, homogeneously throughout the experimental area in both experiments.

\section{Variables analyzed and statistical analysis}

Black oat and common bean crops were evaluated for productivity and nutrient content $\mathrm{Ca}, \mathrm{Mg}, \mathrm{P}, \mathrm{K}, \mathrm{Fe}, \mathrm{Mn}, \mathrm{Zn}$ and $\mathrm{Cu}$ in the shoot of the plants. At the early flowering stage, ten bean plants were randomly collected in each experimental unit. These plant materials were then milled in a Willey mill equipped with a $1 \mathrm{~mm}$ sieve for further chemical analysis. The grain yield of beans was estimated by harvesting $2 \mathrm{~m}$ linear from the two central rows of each experimental unit. The grains obtained after manual threshing were dried to a humidity of $13 \%$ and had their mass determined.

The biomass production of black oat was evaluated by harvesting the shoot of the plants, using a template of 0.8 $\mathrm{m}^{2}$, in the central portion of each experimental unit. The plant material from oats was cut close to the ground at the flowering stage and was taken to determine the dry matter

Table 1. Physical and chemical characterization of soils $(0-20 \mathrm{~cm})$ of experimental areas.

\begin{tabular}{|c|c|c|c|c|c|c|c|c|c|c|}
\hline \multirow{2}{*}{ Soils } & \multirow{2}{*}{$\mathbf{p H}_{(\mathrm{H} 2 \mathrm{O})}$} & $P_{\text {Mehlich }}$ & $\overline{K_{\text {Mehlich }}}$ & $\mathrm{Ca}^{2+}$ & $\mathrm{Mg}^{2+}$ & $\mathrm{Al}^{3+}$ & $\mathrm{H}+\mathrm{Al}$ & $\mathrm{BS}$ & CEC ( $t)$ & $\mathrm{CEC}(\mathrm{T})$ \\
\hline & & \multicolumn{2}{|c|}{$\left(\mathrm{mg} \mathrm{dm}^{-3}\right)$} & \multicolumn{7}{|c|}{$\left(\mathrm{cmol}_{\mathrm{c}} \mathrm{dm}^{-3}\right)$} \\
\hline Exp. I-Porto Vitória - PR & 4.00 & 6.32 & 117.3 & 1.45 & 0.59 & 4.70 & 14.47 & 2.34 & 7.04 & 16.81 \\
\hline \multirow[t]{3}{*}{ Exp. II - Paula Freitas - PR } & 4.30 & 4.54 & 156.4 & 2.84 & 1.49 & 4.95 & 12.13 & 4.73 & 9.68 & 16.86 \\
\hline & V & $m$ & \multirow{2}{*}{$\begin{array}{c}\text { OM } \\
\left(\text { dag kg }^{-1}\right)\end{array}$} & $\mathrm{Fe}$ & & $\mathrm{Cu}$ & $\mathrm{Zn}$ & Sand & Silt & Clay \\
\hline & & & & \multicolumn{4}{|c|}{$\left(\mathrm{mg} \mathrm{dm}^{-3}\right)$} & \multicolumn{3}{|c|}{$(\%)$} \\
\hline Exp. I-Porto Vitória - PR & 13.92 & 66.76 & 50.93 & 104.0 & 30.8 & 6.04 & 1.74 & 23 & 28 & 49 \\
\hline Exp. II - Paula Freitas - PR & 28.05 & 51.14 & 60.31 & 68.76 & 36.8 & 0.69 & 1.28 & 21 & 28 & 51 \\
\hline
\end{tabular}

$\mathrm{P}, \mathrm{K}$ and Micronutrients: extractor Mehlich-1. $\mathrm{Ca}^{2+}$ and $\mathrm{Mg}^{2+}$ : extractor $\mathrm{KCl} 1 \mathrm{~mol} \mathrm{~L}^{-1}$. BS: base sum. OM: organic matter.

Table 2. Chemical and mineralogical characterization of the material resulting from the mixture of dacite and gabbro powders.

\begin{tabular}{|c|c|c|c|c|c|c|c|c|c|}
\hline \multirow{2}{*}{ Main elements } & $\mathrm{SiO}_{2}$ & $\mathrm{Al}_{2} \mathrm{O}_{3}$ & $\mathrm{Fe}_{2} \mathrm{O}_{3}$ & $\mathrm{CaO}$ & $\mathrm{MgO}$ & $\mathrm{K}_{2} \mathrm{O}$ & $\mathrm{Na}_{2} \mathrm{O}$ & $\mathrm{P}_{2} \mathrm{O}_{5}$ & $\mathrm{MnO}$ \\
\hline & \multicolumn{9}{|c|}{$\left(\right.$ dag kg $\left.^{-1}\right)$} \\
\hline Blend (gabbro + dacite) & 55.1 & 14.9 & 10.9 & 8.5 & 4.0 & 1.3 & 2.7 & 0.2 & 0.2 \\
\hline \multirow{2}{*}{ Other elements ${ }^{* 1}$} & $\mathrm{Cu}$ & $\mathrm{Zn}$ & Mo & $\overline{\mathrm{Li}}$ & $\mathrm{Se}$ & $\mathrm{Co}$ & V & $\mathrm{Ni}$ & $S$ \\
\hline & \multicolumn{9}{|c|}{$\left(\mathrm{mg} \mathrm{kg}^{-1}\right)$} \\
\hline Blend (gabbro + dacite) & 149 & 62 & 0.84 & 4 & $<1$ & 18.1 & 199 & 22 & 1900 \\
\hline \multirow{2}{*}{ Other elements ${ }^{* 2}$} & $\mathrm{Hg}$ & $\mathrm{Cd}$ & $\mathrm{Pb}$ & $\mathrm{Be}$ & $\mathrm{Ag}$ & $\mathrm{Cr}$ & As & $\mathrm{Ba}$ & $\mathrm{Sr}$ \\
\hline & \multicolumn{9}{|c|}{$\left(\mathrm{mg} \mathrm{kg}^{-1}\right)$} \\
\hline Blend (gabbro + dacite) & $<0.05$ & 0.06 & 1.7 & 0.3 & 0.09 & 13 & $<1$ & 59 & 119.4 \\
\hline
\end{tabular}

Gabbro: Plagioclase (Labradorite - $45 \%$ ); Clinopyroxene (Augite - $40 \%$ ); Opaques (Magnetite - $15 \%$ ); Olivine (traces)

Dacite: Plagioclase (Andesine / Labradorite - $30 \%$ ); Clinopyroxene (Augite - $20 \%$ ); Opaques (Magnetite - $15 \%$ ); Matrix (fines - 35 \%)

${ }^{1}$ Nutrients to plants or beneficial to other organisms. ${ }^{2}$ Toxic or potentially toxic elements. Lithochemical of the main elements obtained by X-ray Fluorescence and other elements by ICP-EOS. Mineralogical analysis by X-ray diffraction and petrography. 
in a laboratory stove at $65^{\circ} \mathrm{C}$ with forced air circulation for 72 hours. The dry biomass samples of the black oats were then milled for further chemical analysis.

The nutrient contents in the dry matter of the plants were evaluated according to the methodology described in Malavolta et al. (1997), the material being digested in nitroperchloric digestion. The contents of $\mathrm{Ca}, \mathrm{Mg}$ and micronutrients were determined in an atomic absorption spectrophotometer. The levels of $\mathrm{P}$ were determined in a molecular absorption spectrophotometer and the $\mathrm{K}$ values were determined in a flame emission spectrophotometer (Malavolta et al., 1997). At the end of the experiments, composed soil samples from the $0-20 \mathrm{~cm}$ layer of each experimental unit were collected (Dutch auger) to evaluate the chemical characteristics $\mathrm{pH}$ (water), exchangeable acidity $\left(\mathrm{Al}^{3+}\right)$, potential acidity $(\mathrm{H}+\mathrm{Al})$, potential CEC ( $\mathrm{pH}$ 7.0) and availability of $\mathrm{P}, \mathrm{K}, \mathrm{Ca}, \mathrm{Mg}, \mathrm{Fe}, \mathrm{Mn}$, $\mathrm{Zn}, \mathrm{Cu}$ and Si.

Soil chemical characteristics were determined according to the methodologies described in Teixeira et al. (2017) and the availability of nutrients determined in atomic absorption spectrophotometer, molecular absorption or flame photometer after extraction in $\mathrm{KCl} 1 \mathrm{~mol} \mathrm{~L}^{-1}\left(\mathrm{Ca}^{2+}\right.$ and $\left.\mathrm{Mg}^{2+}\right)$ and Mehlich-1 extractor (soil: extractor ratio 1:10) for other essential nutrients. Si available in the soil was extracted by the $0.5 \mathrm{~mol} \mathrm{~L}^{-1}$ acetic acid extracting solution and determined by molecular absorption spectrometry using the blue method.

The data were submitted to the Levene (Med), JarqueBera, Tukey for additivity and Chauvenet tests to evaluate the conditions of homogeneity of variances, residue normality, model additivity and the presence of outliers, respectively. Then, the data were subjected to analysis of variance (ANOVA) and the behavior of doses was evaluated by regression analysis. We considered the significance of the models by the F-test in the ANOVAs of the regressions and the nonsignificance of the lack of fit only for the linear, quadratic, square root, Mitscherlich (exponential), simple exponential and logarithmic models. In addition, the biomass production of black oats and grains yield of beans were submitted to the joint analysis considering the data of experiments I and II. The overall nutritional status of the soil was evaluated by multivariate analysis using the Desirability index (Di). Cohen's " $d$ " statistic was used as an estimate of effect size. Statistical analyzes were performed using SPEED Stat software (Carvalho et al., 2020).

\section{Results and Discussion}

\section{Productivity and soil parameters}

The analysis of variance of the data revealed significant differences between the treatments for some parameters evaluated in both experiments. In the experiment I treatments differed for the soil parameters CTC potential (T), available $P$, available $\mathrm{Cu}$ and for the global multivariate nutritional index (Table 3). In the experiment II the treatments differed for the parameters of potential CTC soil (T), available P, available $\mathrm{Cu}$, available $\mathrm{Zn}$ and for the global multivariate nutritional index (Table 3).

The yield of oat biomass did not differ between treatments in both experiments analyzed alone (Table 3 ). In addition, the joint analysis of the experiments for oat yield data also did not reveal statistically significant differences between the doses of the applied remineralizer.

Bean yield did not differ statistically between treatments, considering the alpha level assumed, in both experiments analyzed separately (Table 3 ). In the joint analysis, however, which simultaneously considers the productivity obtained

Table 3. F values of the analyzes of variance and coefficients of variation (C.V.) of soil parameters, biomass production of black oats (A. strigosa L.) and grain yield of bean (P. vulgaris L.) in the experiments I (Porto Vitória - PR, Brazil) and II (Paula Freitas PR, Brazil).

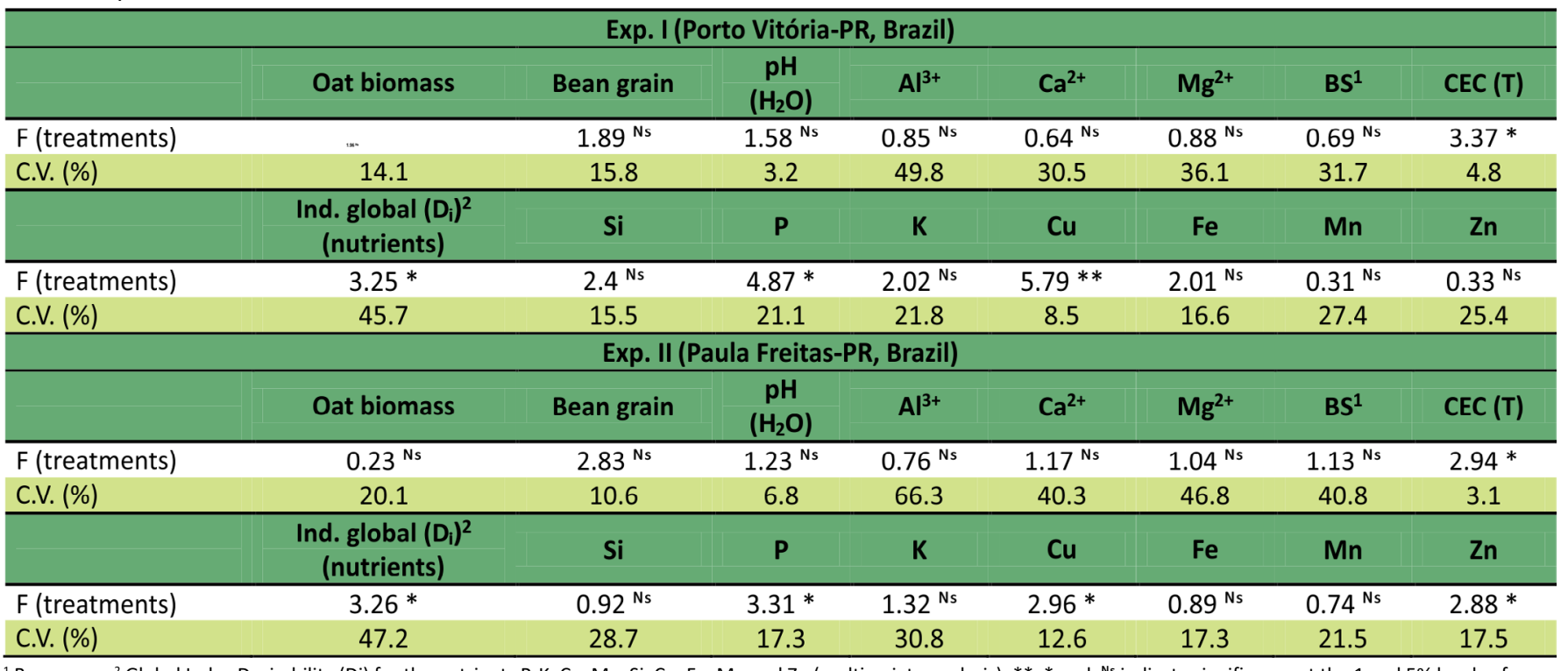

${ }^{1}$ Bases sum. ${ }^{2}$ Global Index Desirability (Di) for the nutrients $\mathrm{P}, \mathrm{K}, \mathrm{Ca}, \mathrm{Mg}, \mathrm{Si}, \mathrm{Cu}, \mathrm{Fe}, \mathrm{Mn}$ and $\mathrm{Zn}$ (multivariate analysis). **, * and ${ }^{\mathrm{N} s}$ indicate significance at the 1 and $5 \%$ levels of error probability, or non-significant, respectively. 
in both experiments, a statistically significant increase was observed (Figure 1). The observed increase in the dose of $7 \mathrm{t} \mathrm{ha}^{-1}$, for example, corresponded to a $16 \%$ increase in productivity compared to the control treatment, or $440 \mathrm{~kg} \mathrm{ha}^{-1}$. Considering that the average grain yield of bean in the state of Paraná (Brazil) is only $1511 \mathrm{~kg} \mathrm{ha}^{-1}$ (Deral-PR, 2018), this increase corresponded to $25 \%$ of the average. This increase in productivity is probably mainly caused by the release of nutrients into the soil by the rocks and the consequent improvement in plant nutrition. Other studies have also demonstrated the ability of basalts and other volcanic rocks to promote plant growth (Shamshuddin \& Anda, 2012; Ramos et al., 2020). Borges (2017), for example, observed gains in the order of $1300 \mathrm{~kg} \mathrm{ha}^{-1}$ in bean yield due to the application of $3 \mathrm{t} \mathrm{ha}^{-1}$ of gabbro.

In the experiment $\mathrm{I}$, the availability of $\mathrm{P}$ was linearly increased, with the mean increase promoted by the remineralizer doses of $28 \%$ ( $d$ Cohen $=1.08$ ) in relation to the control (Figure 2). This increase altered soil $\mathrm{P}$ availability

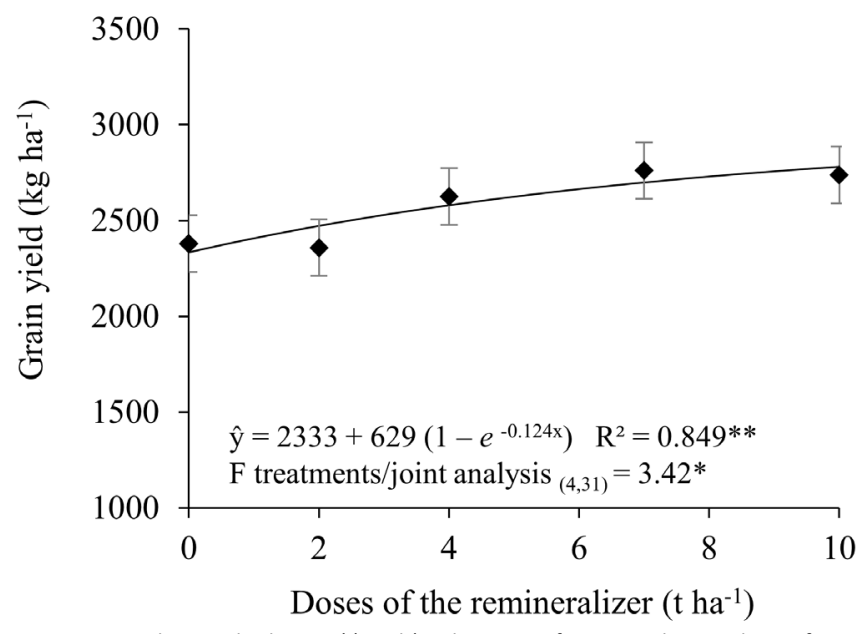

Bars represent the standard error. ${ }^{* *}$ and ${ }^{*}$ indicate significance at the 1 and $5 \%$ of error probability levels.

Figure 1. Grain yield of beans $\left(\mathrm{kg} \mathrm{ha}^{-1}\right)$ as a function of increasing doses of the rock blend. Marginal means of the two experiments evaluated in the joint analysis.
Experiment I
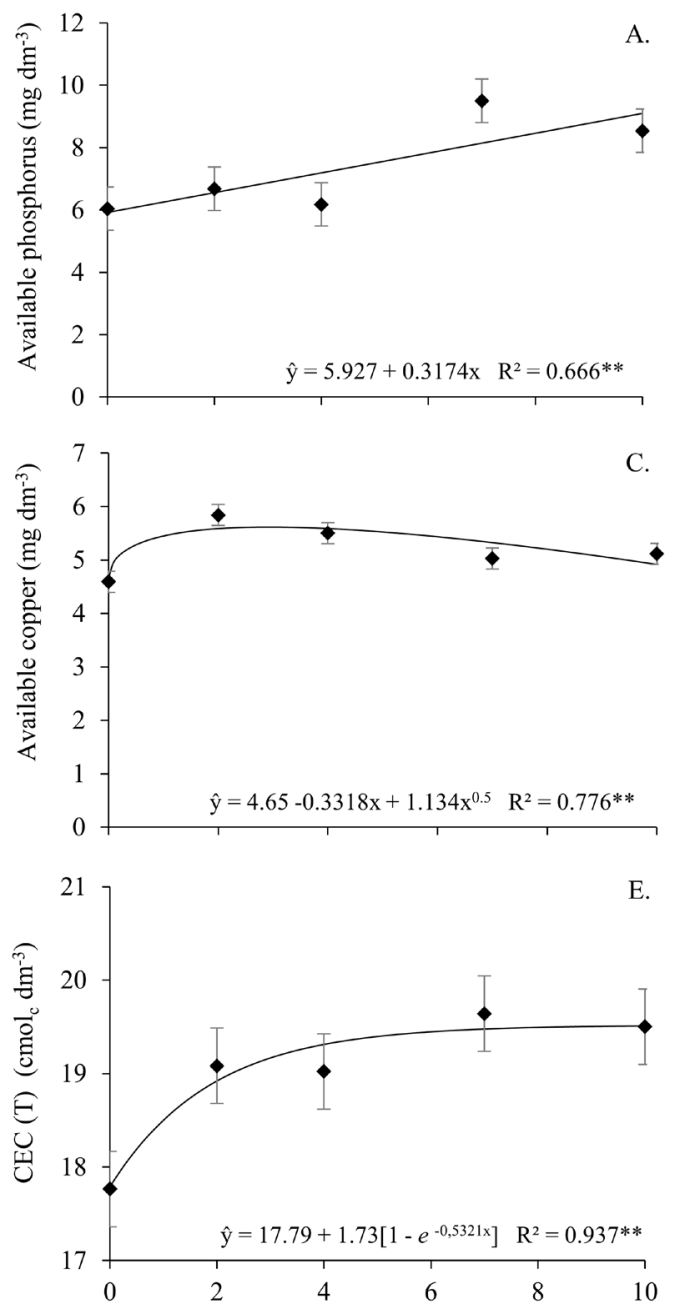

Experiment II
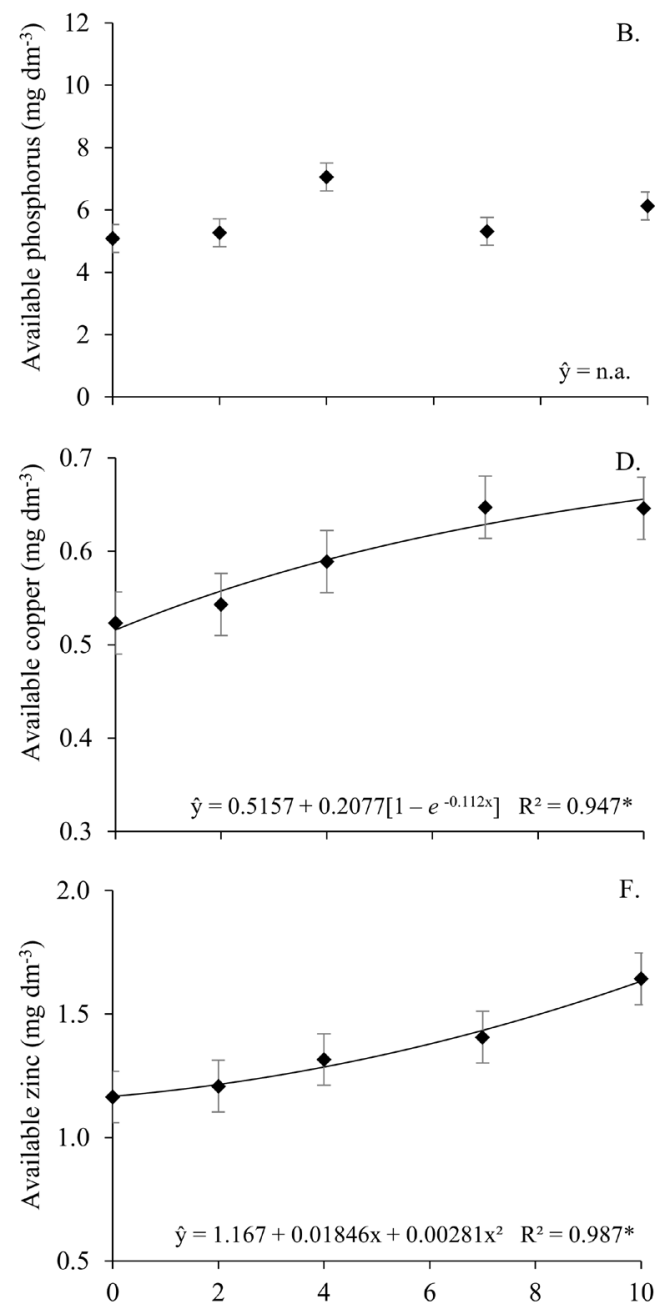

Doses of the remineralizer $\left(\mathrm{t} \mathrm{ha}^{-1}\right)$

Bars represent the standard error. n.a.: There are significant differences, but there was no adjustment to the models of two parameters tested. ** and * indicate the significance of the models at 1 and $5 \%$ of error probability, respectively.

Figure 2. Availability of $\mathrm{P}, \mathrm{Cu}$ and $\mathrm{Zn}$ in soil $\left(\mathrm{mg} \mathrm{dm}^{-3}\right)$ and potential $\mathrm{CEC}$ at $\mathrm{pH} 7.0$ as a function of increasing doses of the remineralizer applied in experiments I and II. 
from "medium" to "high", according to the criteria of SBCSRS/SC (2004). In experiment II, the average increase in P availability in soil promoted by the remineralizer doses was $17 \%$ ( $d$ Cohen $=0.85$ ), but the pattern of this increment was not linear (Figure 2). Increases in the availability of $P$ promoted by basalt powder and related rocks have already been observed in other studies (Shamshuddin \& Anda, 2012; Silva et al., 2012), but not for gabbro and dacite. Possibly, the increase in availability is associated with the presence of $P$ in the remineralizer, but this addition is of small amount (18 kg ha-1 of $\mathrm{P}_{2} \mathrm{O}_{5}$ in the highest dose). Thus, the availability of $\mathrm{P}$ may also have been influenced by the release of $\mathrm{Si}$ in the form of silicates, which may compete for soil phosphate adsorption sites (Tokura et al., 2011; Castro \& Crusciol, 2013; Oliva et al., 2020).

Considering the total $\mathrm{Ca}$ and $\mathrm{Mg}$ contents in the gabbro/ dacite blend (Table 2) and other studies on basalts and related rocks in the literature, it was expected that the $\mathrm{Ca}^{2+}$ and $\mathrm{Mg}^{2+}$ levels in the soil were also increased by the treatments. Several studies have already demonstrated the ability of basalts and other related igneous rocks to provide $\mathrm{Ca}$ in soil or to plants (Shamshuddin \& Anda, 2012; Melo et al., 2012). However, in this work, the adequate initial availability of $\mathrm{Ca}^{2+}$ and $\mathrm{Mg}^{2+}$ in the soil (Table 1) possibly limited the remineralizer response. After all, if there is good availability of a certain element in the soil, plants will not trigger mechanisms to increase access to this nutrient. Furthermore, the hydrolysis reactions of mineral sources of $\mathrm{Ca}$ and $\mathrm{Mg}$ may have their chemical equilibria unfavorably displaced due to the greater activity of $\mathrm{Ca}^{2+}$ and $\mathrm{Mg}^{2+}$ in the soil solution (Mello \& Perez, 2009).

The effect of treatments on the availability of $\mathrm{Cu}$ in soil was more evident in experiment II. In this, the availability of $\mathrm{Cu}$ was increased exponentially, resulting in an average increase of $16 \%$ ( $d$ Cohen $=1.76$ ) in relation to the control (Figure 2 ). This increase allowed the increase of $\mathrm{Cu}$ availability beyond the adequate level of this nutrient in the soil according to the values established by SBCS-RS/SC (2004). Similarly, only in experiment II was there significant statistical evidence of change in soil $\mathrm{Zn}$ availability. The availability of $\mathrm{Zn}$ increased by an average of $19.7 \%$ ( $d$ Cohen $=0.98$ ) in relation to the control (Figure 2). Increases in the availability of micronutrients due to the application of basalt powders and related rocks have also been observed by Melo et al. (2012).

The CEC (T) of the soil was also increased exponentially as a result of increasing doses of the applied remineralizer (Figure 2). The mean increase, promoted by the doses of the remineralizer, was $8.7 \%(\mathrm{~d}$ Cohen $=1.72)$ in relation to the control (Figure 2). This effect, although less than $10 \%$, can be considered high by the size effect measure "d-Cohen" which considers " $d$ " values greater than 0.80 as "high". Possibly, the effect could be more significant if the soil of the experimental area had an initially lower potential CEC. Obtaining the derivative of the adjusted Mitscherlich model (Figure 2), it is estimated that $95 \%$ of the maximum CEC obtained could be reached with only $1.08 \mathrm{t} \mathrm{ha}^{-1}$ of the remineralizer.

Although there was not enough statistical evidence that other nutrients were influenced by treatments, multivariate analysis revealed an overall pattern of improved soil fertility (Figure 3). This pattern of improvement suggests that in the long term, or under the residual effect of successive applications, the remineralizer in question may generate even more significant increases in nutrient availability.

\section{Nutrition of plants}

In the experiment I, the treatments differed statistically from each other for $\mathrm{Mn}$ (bean) and, in experiment II, for $\mathrm{K}$ and $\mathrm{Zn}$ (oat) and $\mathrm{Cu}$ (bean) contents (Table 4). The increase in $\mathrm{Mn}$ contents in the shoots of the bean plants promoted by the different doses of the remineralizer tested was, on average, $10.5 \%$ ( $d$ Cohen $=0.72$ ) in relation to the control treatment $\left(0 \mathrm{t} \mathrm{ha}^{-1}\right)$ (data not shown). This increase allowed a luxury consumption of this nutrient by the bean plants, since the content in the control treatment was already adequate considering the ideal range defined for index leaves of this species (Malavolta et al., 1997).
Experiment 1

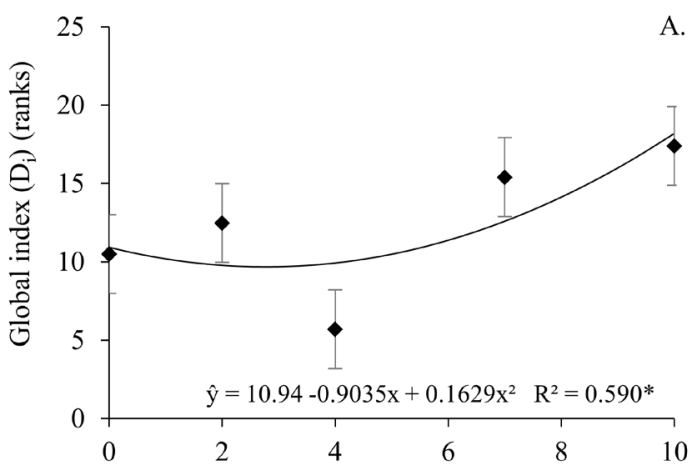

Experiment 2

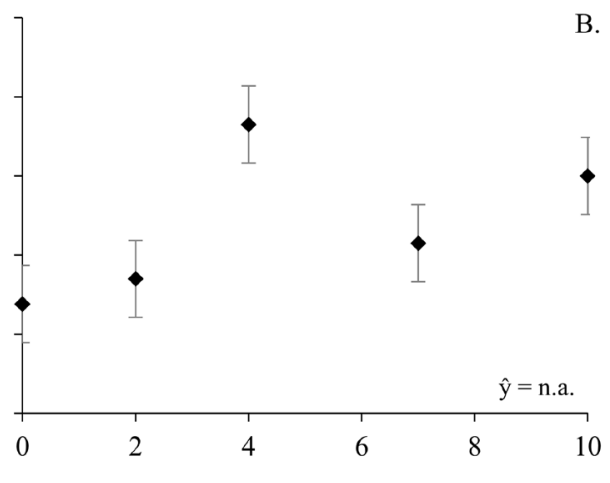

Doses of the remineralizer $\left(\mathrm{t} \mathrm{ha}^{-1}\right)$

Bars represent the standard error. n.a.: There are significant differences, but there was no adjustment to the models of two parameters tested. * Indicates significance of the model at the $5 \%$ of error probability

Figure 3. Global Desirability Index for the nutrients $\mathrm{P}, \mathrm{K}, \mathrm{Ca}^{2+}, \mathrm{Mg}^{2+}, \mathrm{Si}, \mathrm{Cu}, \mathrm{Fe}, \mathrm{Mn}$ and $\mathrm{Zn}$ available in the soil at the end of experiments I and II. 
Table 4. F values of the analyzes of variance and coefficients of variation (C.V.) for nutrient contents in the shoot of black oats (A. strigosa L.) and beans (P. vulgaris L.) in experiments I (Porto Vitória - PR, Brazil) and II (Paula Freitas - PR, Brazil).

\begin{tabular}{|c|c|c|c|c|c|c|c|c|}
\hline \multicolumn{9}{|c|}{ Exp I (Porto Vitória-PR, Brazil) } \\
\hline Black oat & $\mathbf{P}$ & $\mathbf{K}$ & $\mathrm{Ca}$ & $\mathrm{Mg}$ & $\mathrm{Fe}$ & $\mathrm{Zn}$ & $\mathrm{Mn}$ & $\mathrm{Cu}$ \\
\hline $\mathrm{F}$ (treatments) & $0.96^{\mathrm{Ns}}$ & $0.58^{\mathrm{Ns}}$ & $2.35^{\mathrm{Ns}}$ & $0.61^{\mathrm{Ns}}$ & $2.05^{\mathrm{Ns}}$ & $1.39^{\mathrm{Ns}}$ & $0.23^{\mathrm{Ns}}$ & $1.23^{\mathrm{Ns}}$ \\
\hline C.V. (\%) & 13.4 & 27.7 & 8.2 & 9.3 & 22.6 & 8.5 & 12.4 & 6.6 \\
\hline Bean & $\mathbf{P}$ & K & $\mathrm{Ca}$ & $\mathrm{Mg}$ & $\mathrm{Fe}$ & $\mathrm{Zn}$ & $\mathrm{Mn}$ & $\mathrm{Cu}$ \\
\hline $\mathrm{F}$ (treatments) & $0.59^{\mathrm{Ns}}$ & $1.01^{\mathrm{Ns}}$ & $0.77^{\mathrm{Ns}}$ & $0.75^{\mathrm{Ns}}$ & $0.83^{\mathrm{Ns}}$ & $1.19^{\mathrm{Ns}}$ & $4.04 *$ & $0.35^{\mathrm{Ns}}$ \\
\hline C.V. (\%) & 3.5 & 8.5 & 3.8 & 8.8 & 18.6 & 7.9 & 13.6 & 7.6 \\
\hline \multicolumn{9}{|c|}{ Exp II (Paula Freitas-PR, Brazil) } \\
\hline Black oat & $\mathbf{P}$ & $\mathbf{K}$ & $\mathrm{Ca}$ & $\mathrm{Mg}$ & $\mathrm{Fe}$ & $\mathrm{Zn}^{1}$ & $M n$ & $\mathrm{Cu}$ \\
\hline $\mathrm{F}$ (treatments) & $1.37^{\mathrm{Ns}}$ & $6.14^{* *}$ & $1.84^{\mathrm{Ns}}$ & $1.27^{\mathrm{Ns}}$ & $1.95^{\mathrm{Ns}}$ & $3.97^{*}$ & $1.26^{\mathrm{Ns}}$ & $2.29^{\mathrm{Ns}}$ \\
\hline C.V. (\%) & 5.9 & 8.6 & 15.9 & 14.2 & 25.8 & 4.7 & 21.2 & 10.9 \\
\hline Bean & $\mathbf{P}$ & $\mathrm{K}$ & $\mathrm{Ca}$ & $\overline{M g}$ & $\mathrm{Fe}$ & $\mathrm{Zn}$ & $M n$ & $\mathrm{Cu}$ \\
\hline $\mathrm{F}$ (treatments) & $2.19^{\mathrm{Ns}}$ & $2.33^{\mathrm{Ns}}$ & $1.27^{\mathrm{Ns}}$ & $0.84^{\mathrm{Ns}}$ & $0.2^{\mathrm{Ns}}$ & $0.95^{\mathrm{Ns}}$ & $0.51^{\mathrm{Ns}}$ & $2.86 *$ \\
\hline C.V. (\%) & 5.9 & 7.2 & 9.2 & 10.8 & 35.8 & 14.2 & 21.5 & 9.4 \\
\hline
\end{tabular}

${ }^{1}$ Transformed data for $\ln (y+1)^{3}$ to satisfy parametric assumptions. ${ }^{* *},{ }^{*}$ and ${ }^{\mathrm{Ns}}$ indicate significance at the 1 and $5 \%$ levels of error probability, or non-significant, respectively.

In experiment II, there were $22 \%$ increments in $\mathrm{K}$ contents at the dose corresponding to $7 \mathrm{t} \mathrm{ha}^{-1}$ in relation to the control (Figure 4). The mean increase, however, was only $8.2 \%$ due to a possibly anomalous effect in treatment 3 , an effect also observed for the $\mathrm{Zn}$ contents in the plants of the black oats (Figure 4).

The increase in $\mathrm{Cu}$ contents in the shoots of the bean plants promoted by the different doses of the remineralizer tested was, on average, $13 \%$ ( $d$ Cohen $=1.27$ ) in relation to the control treatment (Figure 4). The maximum value estimated by the model was $11.96 \mathrm{mg} \mathrm{dm}^{-3}$, reached at the dose corresponding to $6.2 \mathrm{t} \mathrm{ha}^{-1}$ of remineralizer. This increase suggests that the remineralizer may have also influenced the availability of soil reserves, probably by stimulating the mineralization of organic matter.

The ability to increase the availability of micronutrients in the soil promoted by the addition of powders of silicate rocks has already been evidenced in other studies (Silva et al., 2014), but in a still very limited set of evidences and not for gabbro and dacite. Silicate rocks are mostly slow-release multi-nutrient sources, but it is necessary to distinguish which ones have higher levels of nutrients and which have a minimum reactivity for the effects to be perceptible in the short term. In this context, one of the great challenges of
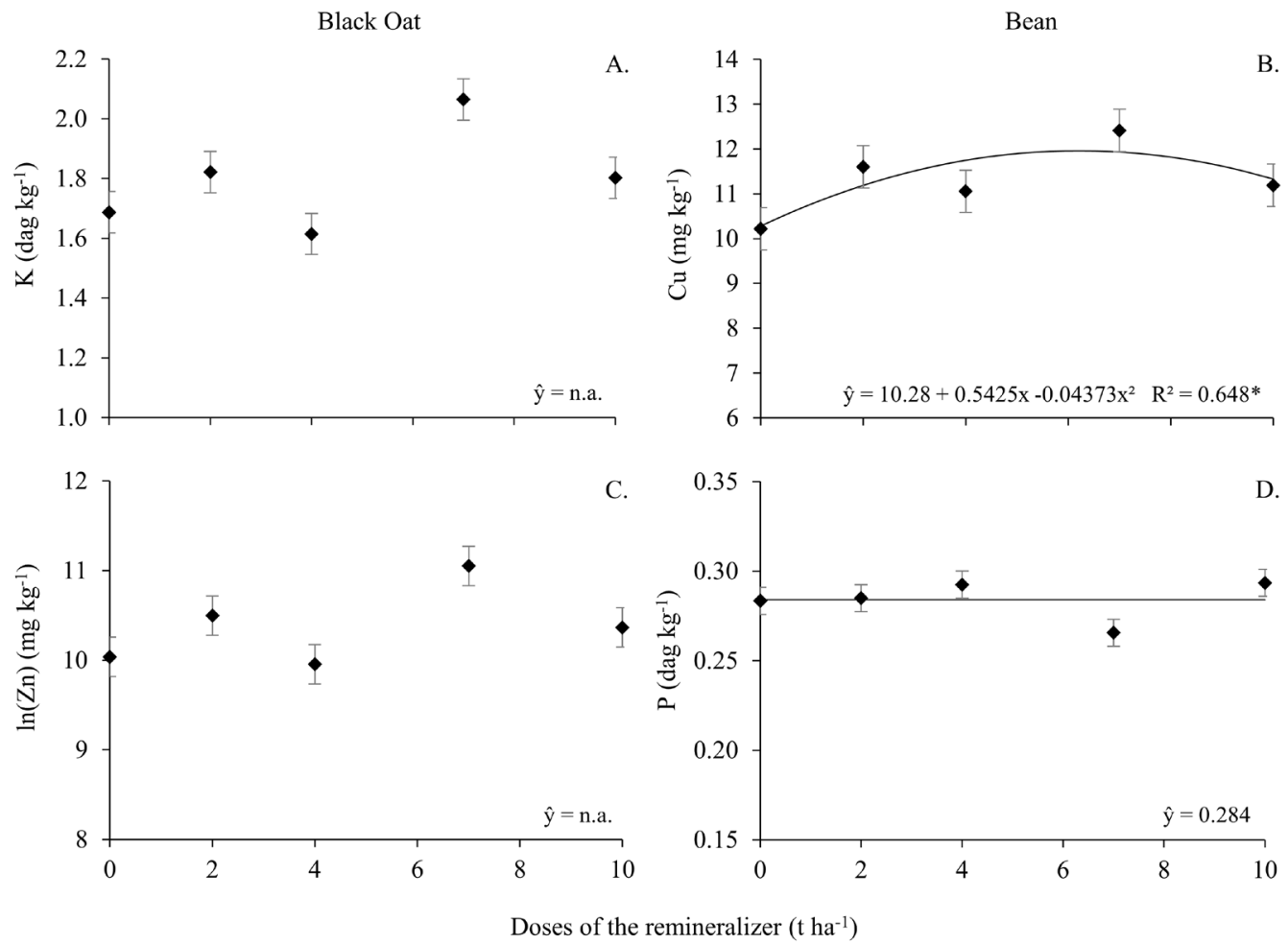

Bars represent the standard error. n.a.: There are significant differences, but there was no adjustment to the models of two parameters tested. * Indicates significance of the model at the $5 \%$ of error probability.

Figure 4. Nutrient contents in the shoot of the oat plants ( $\mathrm{K}$ and $\mathrm{Zn}$ ) and beans ( $\mathrm{Cu}$ and $\mathrm{P}$ ) as a function of increasing doses of the rocks powder applied in experiment II (Paula Freitas - PR, Brazil). 
rock powder use is the screening of the enormous diversity of rocks available, in order to identify those with the best potential. This work shows, for the first time, the agronomic viability of the gabbro-dacite blend and opens up a range of possibilities for rethinking strategies to improve the utilization of these resources.

Evidently, this work is limited by elucidating only the effect of gabbro-dacite blend on plant growth and some soil chemical attributes. There is much to discover and understand about the effect of these materials on soil structure and the soil microbial community. As natural materials with a low saline effect, the potential for negative impact of stonemeal on the physical and biological quality of the soil is low (Beerling et al., 2018; Carvalho et al., 2018). In addition, there is evidence that some microorganisms can enhance the solubilization of these materials (Sindhu et al., 2016), which reinforces the importance of evaluating biochemical and microbiological attributes in future work on this topic.

\section{Conclusions}

Application of the rock blend results in increased grain yield of beans and overall improvement of nutritional status of the soil, although this improvement has been more evident only for phosphorus, copper and zinc.

The application of the remineralizer results in an increase in the leaf contents of the potassium, zinc, copper and manganese.

The material obtained by the gabbro-dacite blend, in the ratio of tested mixture, is a multi-nutrient source with agronomic viability.

\section{Acknowledgements}

We thank the Coordenação de Aperfeiçoamento de Pessoal de Nível Superior (CAPES) and to the Fundação de Amparo à Pesquisa do Estado de Minas Gerais (FAPEMIG) for the scholarship of one of the authors.

\section{Compliance with Ethical Standards}

Author contributions: Conceptualization: FJPS, AMXC; Data curation: FJPS, PHCB; Formal analysis: $A M X C, P H C B$; Funding acquisition: $A M X C$; Investigation: FJPS, $\mathrm{PHCB}$; Methodology: FJPS, AMXC; Supervision: AMXC; Writing original draft: $A M X C, P H C B$; Writing - review \& editing: $A M X C$, PHCB.

Conflict of interest: We declare a potential conflict of interest because one of the authors has a direct interest in the results, although this has been accompanied by the others. There was also private funding for the research.

Financing source: The Coordenação de Aperfeiçoamento de Pessoal de Nível Superior (CAPES) - Finance Code 001, Conselho Nacional de Desenvolvimento Científico e
Tecnológico (CNPq), Fundação de Amparo à Pesquisa do Estado de Minas Gerais (FAPEMIG), AS-PTA and Ekosolos.

\section{Literature Cited}

Basak, B. B.; Sarkar, B.; Naidu, R. Environmentally safe release of plant available potassium and micronutrients from organically amended rock mineral powder Environmental Geochemistry and Health, v.43, p.3273-3286, 2021. https://doi.org/10.1007/ s10653-020-00677-1.

Beerling, D. J.; Leake, J. R.; Long, S. P.; Scholes, J. D.; Ton, J.; Nelson, P. N.; Bird, M.; Kantzas, E.; Taylor, L. L.; Sarkar, B.; Kelland, M.; Delucia, E.; Kantola, I.; Muller, C.; Rau, G. H.; Hansen, J. Farming with crops and rocks to address global climate, food and soil security. Nature Plants, v.4, p.138-147, 2018. https://doi. org/10.1038/s41477-018-0108-y.

Borges, P. H. C. Sistematização de experiências e efeitos da adubação verde e da granulometria de pós de rochas. Rio Paranaíba: Universidade Federal de Viçosa, 2017. 50p. Master's Thesis. https://locus.ufv.br//handle/123456789/10823. 06 Sep. 2021.

Carvalho, A. M. X.; Cardoso, I. M.; Theodoro, S. H. M.; Souza, M. E. P. Rochagem: o que se sabe sobre essa técnica? In: Cardoso, I. M.; Fávero, C. (Orgs.). Solos e agroecologia. 1.ed. Brasília: Embrapa, 2018. v.4, p.101-128. (Embrapa. Coleção Transição Agroecológica, v.4).

Carvalho, A. M. X.; Mendes, F. Q.; Mendes, F. Q.; Tavares, L. F. SPEED Stat: a free, intuitive, and minimalist spreadsheet program for statistical analyses of experiments. Crop Breeding and Applied Biotechnology, v.20, n.3, e327420312, 2020. https://doi. org/10.1590/1984-70332020v20n3s46.

Castro, G. S. A.; Crusciol, C. A. C. Effects of superficial liming and silicate application on soil fertility and crop yield under rotation. Geoderma, v.195-196, n.2, p.234-242. 2013. https://doi. org/10.1016/i.geoderma.2012.12.006.

Departamento de Economia Rural - Deral-PR. Secretaria da Agricultura e Abastecimento do Estado do Paraná - Dados de Produção Agropecuária 2017. http://www.agricultura.pr.gov.br/modules/ conteudo/conteudo.php?conteudo=137. 31 Aug. 2018.

Gotz, L.F.; Castamann, A.; Piovesan, F.; Anzolin, B. L.; Herek, T. A.; Mikoanski, W. M.; Rita, Y. L. Use of rock powder associated with bovine manure in Latossolo Vermelho cultivated with wheat. Revista Brasileira de Agropecuária Sustentável, v.9, n.2, p.131139, 2019. https://doi.org/10.21206/rbas.v9i2.3464.

Machado, R. V.; Andrade, F. V.; Passos, R. R.; Ribeiro, R. C. C.; Mendonça, E.S. Characterization of ornamental rock residue and potassium liberation via organic acid application. Revista Brasileira de Ciência do Solo, v.40, e0150153, 2016. https://doi. org/10.1590/18069657rbcs20150153.

Malavolta, E.; Vitti, G. C.; Oliveira, S. A. Avaliação do estado nutricional das plantas: princípios e aplicações. 2.ed. Piracicaba: Potafós, 1997. 319p.

Mancuso, M. A. C.; Soratto, R. P; Crusciol, C. A. C; Castro, G. S. A. Effect of potassium sources and rates on arabica coffee yield, nutrition, and macronutrient export. Revista Brasileira de Ciência do Solo, v.38, n.6, p.1448-1456, 2014. https://doi.org/10.1590/ $\underline{\text { s0100-06832014000500010. }}$ 
Mello, J. W. V.; Perez, D. V. Equilíbrio químico das reações no solo. In: Melo, V. F.; Alleoni, L. R. F. (Eds.). Química e mineralogia do solo - parte I. Viçosa: SBCS, 2009. p.151-250.

Melo, V. F.; Uchôa, S. C. P.; Dias, F. O.; Barbosa, G. F. Doses de basalto moído nas propriedades químicas de um Latossolo Amarelo distrófico da savana de Roraima. Acta Amazônica, v.42, n.3, p.471-476, 2012. https://doi.org/10.1590/S004459672012000400004.

Oliva, K. M. E.; Nascimento, C. W. A.; Silva, F. B. V.; Araújo, P. R. M.; Oliveira, E. C. A.; Feitosa, M. M.; Lima, L. H. V. Biomass and concentration of nutrients and silicon in sugarcane grown on soil fertilized with diatomite. Revista Brasileira de Ciências Agrárias, v.15, n.4, e8755, 2020. https://doi.org/10.5039/agraria. v15i4a8755.

Ramos, C. G.; Medeiros, D. S.; Gomez, L.; Oliveira, L. F. S.; Schneider, I. A H.; Kautzmann, R. M. Evaluation of soil re-mineralizer from by-product of volcanic rock mining: experimental proof using black oats and maize crops. Natural Resources Research, v.29, n.3, p.1583-1600, 2020. https://doi.org/10.1007/s11053-01909529-x.

Ramos, C. G.; Querol, X.; Dalmora, A. C.; Pires, K. C. J.; Schneider, I. A. H.; Oliveira, L. F. S.; Kautzmann, R. M. Evaluation of the potential of volcanic rock waste from southern Brazil as a natural soil fertilizer. Journal of Cleaner Production, v.142, n.4, p.2700-2706, 2017. https://doi.org/10.1016/j.jclepro.2016.11.006.

Sociedade Brasileira de Ciência do Solo; Comissão de Química e Fertilidade do Solo do RS/SC - SBCS-RS/SC. Manual de adubação e de calagem para os estados do Rio Grande do Sul e de Santa Catarina. Porto Alegre: SBCS, 2004. 400p.

Shamshuddin, J.; Anda, M. Enhancing the productivity of Ultisols and Oxisols in Malaysia using basalt and/or compost. Pedologist, v.55, n.3, p.382-391, 2012. https://doi.org/10.18920/ pedologist.55.3 382.

Silva, D. R. G.; Marchi, G.; Spehar, C. R.; Guilherme, L. R. G.; Rein, T. A.; Soares, D. A. Characterization and nutrient release from silicate rocks and influence on chemical changes in soil. Revista Brasileira de Ciência do Solo, v.36, n.5, p.951-962, 2012. https:// doi.org/10.1590/S0100-06832012000300025.

Silva, D. R. G.; Spehar, C. R.; Marchi, G.; Soares, D. A.; Cancellier, E. L.; Martins, E.S. Yield, nutrient uptake and potassium use efficiency in rice fertilized with crusched rocks. African Journal of Agricultural Research, v.9, n.4, p.455-464, 2014. https://doi. org/10.5897/AJAR2013.7638.
Sindhu, S. S.; Parmar, P.; Phour, M.; Sehrawat, A. Potassiumsolubilizing microorganisms (KSMs) and its effect on plant growth improvement. In: Meena, V. S.; Maurya, B. R.; Verma, J. P.; Meena, R. S. (Eds). Potassium solubilizing microorganisms for sustainable agriculture. Nova Delhi: Springer, 2016. p.171-186. https://doi.org/10.1007/978-81-322-2776-2 13.

Souza, M. E. P.; Cardoso, I. M.; Carvalho, A. M. X.; Lopes, A. P.; Jucksch, I.; Janssen, A. Rock powder can improve vermicompost chemical properties and plant nutrition: an on-farm Experiment. Communications in Soil Science and Plant Analysis, v.49, n.1, p.112, 2018. https://doi.org/10.1080/00103624.2017.1418372.

Swoboda, P.; Döring, T.; Hamer, M. Remineralizing soils? The agricultural usage of silicate rock powders: A review. Science of The Total Environment, v.807, part 3, e150976, 2021. https://doi. org/10.1016/i.scitotenv.2021.150976.

Tavares, L. F.; Carvalho, A. M. X.; Camargo, L. G. B.; Pereira, S. G. F.; Cardoso, I. M. Nutrients release from powder phonolite mediated by bioweathering actions. International Journal of Recycling of Organic Waste in Agriculture, v.7, n.1, p.89-98, 2018. https://doi. org/10.1007/s40093-018-0194-x.

Teixeira, P. C.; Donagemma, G. K.; Fontana, A.; Teixeira, W. G. Manual de métodos de análise de solo. 3ed. Brasília: Embrapa, 2017.574p.

Tokura, A. M.; Furtini Neto, A. E.; Carneiro, L. F.; Curi, N.; Santos, J. Z. L. Dinâmica das formas de fósforo em solos de textura e mineralogia contrastantes cultivados com arroz. Acta Scientiarum: Agronomy, v.33, n.2, p.171-179, 2011. https://doi.org/10.4025/actasciagron v33i1.1435.

Wang, M.; Gao, L.; Dong, S.; Sun, Y.; Shen, Q.; Guo, S. Role of silicon on plant-pathogen interactions. Frontiers in Plant Science, v.8, a701, 2017. https://doi.org/10.3389/fpls.2017.00701.

Willer, H.; Travnicek, J.; Meier, C.; Schlatter, B. The world of organic agriculture - statistics and emerging trends 2021. Bonn: Research Institute of Organic Agriculture FiBL and IFOAM, 2021. 340p. https://www.fibl.org/fileadmin/documents/shop/1150-organicworld-2021.pdf. 06 Sep. 2021.

Zoroddu, M. A.; Aaseth, J.; Crisponi, G.; Medici, S.; Peana, M.; Nurchi, V. M. The essential metals for humans: a brief overview. Journal of Inorganic Biochemistry, v.195, p.120-129, 2019. https://doi. org/10.1016/i.jinorgbio.2019.03.013. 